\title{
THE POTENTIAL OF THE DEVELOPMENT OF ECOTOURISM IN THE REPUBLIC OF MOLDOVA THROUGH THE PRISM OF NATIONAL TOURIST AREAS
}

\begin{abstract}
The Republic of Moldova is an important area for tourism, rich in natural objectives and complexes allowing the development of a sustainable form of tourism - ecotourism. Therefore, it is worth noting the presence of natural ecosystems that have the potential for ecotourism development in the protected areas and other natural territories, which have good natural conditions for outdoor activities, such as: hiking, flora and fauna observation, sports and cultural activities. This study presents the analysis of the Republic of Moldova protected natural areas which are 8 national tourist zones with major opportunities for the ecotourism development.
\end{abstract}

Keywords: tourism, ecotourism, tourist areas, tourist potential, reservations, natural areas.

\section{INTRODUCTION}

Ecotourism is one of the areas of scientific and practical concern in most countries of the world, as it contributes to sustainable development through its activities. The modest geographic dimensions of urban areas in the Republic of Moldova cannot allow mass tourism to take place. Ecotourism reveals a real opportunity for the development of the country's areas that have the resources and conditions necessary for its revaluation. Ecotourism is a safe alternative for capitalizing on natural landscapes and ecological biodiversity in international tourist attractiveness.

The aim of the research is to identify ways of developing and promoting ecological tourism in the Republic of Moldova as a business opportunity with its substantial advantages.

Methodology of research. Research methods in the investigation and elaboration of the scientific approach have served: observation method, induction and deduction, logical analysis and synthesis, investigation method, analogy and comparison.

\footnotetext{
${ }^{1}$ Maria Hămuraru, PhD, Associate Professor, Moldova State University str. Alexe Mateevici, 60 Chisinau,MD-2009 Republic of Moldova; e-mail: maria.gamurari@gmail.com (corresponding author). ORCID: 0000-0002-8197-2973.

2 Adriana Buzdugan, PhD, Associate Professor, Moldova State University str. Alexe Mateevici, 60 Chisinau,MD-2009 Republic of Moldova; e-mail: buzdugan.adriana@gmail.com. ORCID: 0000-0002-1551-7964.
} 
Concepts on ecotourism. One of the first eco-tourism definitions found in the specialist literature has been in 1988 within the Belize Program initiated by Rio Bravo Conservation \& Management Area: "Ecotourism is a form of low impact environmental tourism based on its appreciation and where a conscious effort is made to re-invest an appropriate portion of revenue to conserve the resources on which it relies. It is a form of sustainable tourism that provides benefits to the local population" According to Hector Ceballas Lascurain (1983), "Ecotourism is a tourism that involves travel in relatively unobtrusive areas for the purpose of admiring, studying, enjoying landscapes, fauna, plants, and some cultural resources". Cater Erlet says that alongside nature must be some anthropic resources, stating that ecotourism is "a journey to human enjoyment based on the diversity of natural life and human culture without causing destruction or degradation", a definition that is much closer of ecotourism. According to D. Weaver (2002), ecotourism is "a form of tourism based on experiences of studying and appreciating the natural environment as well as its other components, all contained within the social context in that area". He argues that the protection of the environment and culture, in the manner of sustainable development principles, will enrich the basic natural and cultural resources of the destination and promote the viability and the pursuit of this activity.

In the Republic of Moldova, the term ecotourism is defined as a form of tourism oriented towards the knowledge of nature and its preservation, within the Law on the organization and development of tourism activity in the Republic of Moldova (no. 352 of 24.11.2006).

Although some details vary in concept definition, most ecotourism approaches reflect the same basic criteria that need to be emphasized. Thus, generalizing the above and at the same time representing the author's point of view, we can conclude that "ecotourism is a form of tourism carried out in natural areas, whose purpose is to know and appreciate local nature and culture, conservation and ensures active involvement, generating benefits for the local population". Thus, ecotourism is regarded as a concept with principles, as a business opportunity and as an evolving market segment, being a form of tourism in natural areas.

\section{THE TOURIST POTENTIAL OF THE REPUBLIC OF MOLDOVA}

The Republic of Moldova has a rich natural environment in terms of landscape diversity and geomorphology. The diversity of landscapes is heightened by the numerous forest lands, steppe, river meadows, rocky terrain, and others. Even if it is a quite small country, the tourist potential of the Republic of Moldova is quite significant in terms of natural monuments and historical-cultural values that allow the broad development of ecotourism. Representative elements of the natural potential, which can provide a quality that is necessary for the development of ecotourism, are: the relief (plateaus, hills and plains, the altitude of the relief in the Republic of Moldova ranges from 4 meters to 429 meters, the average altitude is about 150 of meters); climate (temperate-continental is formed due to the position of the country at approximately equidistant distance from the equator and the North Pole); hydrographic network (the reserves of Moldova's waters are quite modest); vegetation (varied and rich in species, two areas of vegetation are distinguished in Moldova: steppe and silviculture); fauna (animals living in forests, plains, plateaus are distinguished, some rodents are characteristic of steppe regions, there are swans in lakes and ponds, various species of fish storks). Due to the unbalanced exploitation of these representative elements of the natural environment, especially the fauna, flora and waters that are most sensitive to 
the uncontrolled human impact, have emerged territories with special protection status, which are termed natural protected areas.

State-owned natural areas are defined as "bulky areas of biosphere including dry and aquatic areas that are totally or partially permanently or temporarily excluded from the intensive economic and tourism circuit and are intended to protect and improve the quality of the environment, conservation and safeguarding natural resources, the protection of objects and natural or artificial phenomena of scientific value".

Areas protected by natural value and low levels of human intervention on their territory are the best examples and models for natural and semi-natural ecological systems. Thus, both the assessment and monitoring of the state of natural capital, as well as the development of knowledge, can be achieved in pilot areas such as protected areas.

The State Protected Areas Fund of the Republic of Moldova includes natural objectives and complexes of primary value for conservation of biodiversity and economic equilibrium and for the ecological education of the population. These are categories of natural objects and complexes: scientific reservations, natural reservations, landscape reservations, nature monuments, national parks, botanical gardens, dendrological gardens, multipurpose areas, zoological gardens, biosphere reserves etc. Objects and complexes in protected areas are of international, national and local importance.

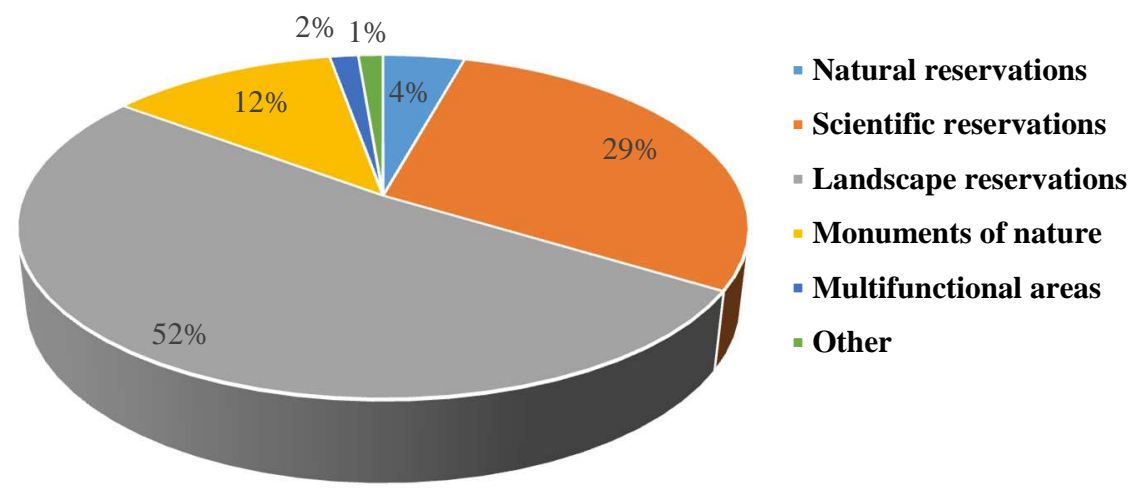

Figure 1. The protected areas functional structure

Source: elaborated by author.

The main objective of the natural reserves is to provide optimal conditions for protection and recovery of different species, plant communities and significant animals, that are nationally important. The most representative natural forest reserves are: Rososeni (Briceni), Baurci (Cahul), Sadova (Călărași), Flamanda (Vulcănești). We also have nine natural medicinal herb reserves: Roșcani (Briceni), Hrușca (Camenca), Logănești (Hâncești), Seliște (Nisporeni), that protect and preserve different medicinal herb species. There are also mixed reserves, such as Cantemir (Cantemir), Lebăda Albă (Leova) and Togai (Ștefan Vodă).

The priority objective of the scientific reserves are environmental protection, scientific research and people's ecological education. There are some important reserves in Republic of Moldova, that are interesting for tourists and scientists. They are: Plaiul Fagului 
(Ungheni), Iagorlâc (Lozova), Prutul de Jos (Cahul), Pădurea Domnească (Glodeni), Codru (Strășeni).

The objective of the landscape reserves is to preserve nationally important natural landscapes. Their use is regulated for economic, touristic, cultural and recreational purposes. The most representive reserves are: Pădurea Hârbovăț (Anenii Noi), The geological and palaontological complex of Lopatnic River (Briceni), Lunca inundalilă (Cantemir), Codri Tigheci (Cantemir), Suta de Movile (Rașcani), Cosăuți (Soroca), Carbuna (Căinari).

The Monuments of nature preserve and contain the history and beauty of our country. Scientist often do research there.

The resource reserves are created in order to protect some types of soils and resources in their natural condition. It also includes preservation of artificial diversity, such as: botanical gardens, dendrological gardens, zoological gardens and other landscape monuments. People, usually, create different plant and animal collections in these reserves for educational, informational and touristic purposes.

The objective of the landscape architecture monuments is to protect and capitalize architectonic landscape compositions, that serve as a gene pool deposit for plants.

1 table represents the number and the surface of Moldova's protected areas.

Table 1. The protected area categories from the Republic of Moldova

\begin{tabular}{|c|c|c|c|}
\hline №. & The protected area categories & Number & Surface, ha \\
\hline 1 & Scientific reserves & 5 & 19378,0 \\
\hline 2 & $\begin{array}{l}\text { Monuments of nature: } \\
\text { - geological and palaeontological; } \\
\text { - hydrological; } \\
\text { - botanical. }\end{array}$ & $\begin{array}{l}86 \\
31 \\
13\end{array}$ & $\begin{array}{c}2681,8 \\
99,8 \\
125,2 \\
\end{array}$ \\
\hline 3 & $\begin{array}{l}\text { Natural reserves: } \\
\text { - forestry; } \\
\text { - of medicinal herbs; } \\
\text { - mixed. } \\
\end{array}$ & $\begin{array}{c}51 \\
9 \\
3 \\
\end{array}$ & $\begin{array}{c}5001,0 \\
2796,0 \\
212,0 \\
\end{array}$ \\
\hline 4 & Landscape reserves & 41 & 34200,0 \\
\hline 5 & Resource reserves & 13 & 532,0 \\
\hline 6 & Multifunctional management areas & 27 & 1029,0 \\
\hline 7 & Botanical gardens & 1 & 105,0 \\
\hline 8 & Dendrological gardens & 2 & 104,0 \\
\hline 9 & Zoological gardens & 1 & 20,0 \\
\hline 10 & Landscape architectury monuments & 21 & 304,9 \\
\hline 11 & Urban zones & 3 & 94705 \\
\hline & Total & 470 & 161286,1 \\
\hline
\end{tabular}

Source: elaborated by the author.

The natural protected areas from the Republic of Moldova represents the key-point for ecotourism practice, as I mentioned, they are represented by 5 forestry scientific reserves, 63 natural reserves, 130 monuments of nature with increased interest for tourists, 41 landscape reserves, that offer relaxing and informational possibilities for tourists, 13 resource reserves, 27 multifunctional management areas, that are divided in 5 steppe vegetation sec- 
tions, 25 meadow vegetation and 2 forest curtains sections, 1 botanical garden, 2 dendrological gardens and 1 zoological garden. These sections form internal ecotouristic offer, we only should protect and capitalize these beautiful places of Moldova.

There are hundreds of ecotouristc important places in Republic of Moldova, that worth be exploited by internal tourists, which are well known and promoted.

The natural fund formed by botanical objectives: forest and forestry reserves, parks, botanical and denrological gardens, secular trees, forestry sections, steppe flora plots and others, represent imposing touristic resources in ecotouristic activities.

The most attractive seasons for ecotourists are spring and early summer, when they can admire the growth of such plants as acacia, that are recorded in 76 similar areas. The beautiful images and flavour of these areas is an attraction, that could be the base of special ecotouristic trips, where we could include also acacia honey degustation, made by local masters. This element could be supplementary, highly-appreciated by tourists service.

Some settlements views, that are specific because of their unique landform contrasts, represents an exclusive value for the Republic of Moldova and ,also, an important ecotouristic value, because this is central ecotouristic place. Fruits, grapes, honey, the delicious products made by locals, that promote healthy lifestyle, are pure ecological products, that could by the main point of attraction four foreign ecotourists. The Republic of Moldova could be a refuge for ecotourists, that everyday live in urban environment, who want a shelter or a relaxing place with an advantageous price, compared to other countries with developed ecotourism.

The protected areas, especially national parks, natural reserves, biospherical reserves, landscape architecture monuments get a real touristic value.

As a result of natural areas analize in the Republic of Moldova, we can distinguish eight touristic zones with major potential:

1. Touristic zone Edineț-Ocnița with three subareas: Edineț, Ocnița and Dondușeni. This zone is beautiful for it`s exclusive natural monuments and cultural-historycal objectives. The main touristic attractions are geological reserves: Naslavcea, Mereșeuca; Dendrological parks: Țaul, Mândâc, Caracușeni; Landscape and recreative forests: Gârbova, Tețcani, Giordinești; Secular oak trees: Brânzeni; Karst landscape monuments: Crive cave, Fetești, Brânzeni, Caracușeni, Butești, Horodiște, the Prut toltres - unique monument for entire Europe; Water storage: Costești-Stânca. This offer could be completed by different historical-cultural objectives, such as churches - historical and art monuments - Larga, Lipcani, Pererîta, Criva, Corjeuți, Petrușeni, Otaci, Mărcăuți, Nădărăuți, Codreanca etc., Archeological points: Butești-keys, Duruitoarea cave. This zone offers good conditions for developing of a relaxing, scintific, cultural and ecological tourism, beacuse some of regions from this zone, such as Ocnița and Edineț, are part of „Prutul de sus” Euroregion, that allows developing of infrastructure and territory improvement, transport and communication route extension, provide ecological security and many other benefits, as a result of border cooperation.

The ecotourism offer can also be complemented by many cultural and historical objectives, such as churches - historical and art monuments - from Larga, Lipcani, Pererita, Criva, Corjeuti, Petruseni, Otaci, Marcauti, Nadarauti, Codreanca etc., archaeological sites: Keys from Buteşti, Duruitoarea cave. This area offers conditions for the development of recreational and recreational tourism, scientific, cultural and especially ecotourism, as some regions of the given area, such as Ocnita, Edinet, are part of the "Prutul de sus" Euroregion, which allows the harmonization infrastructure development and spatial planning, extension 
of transport and communications routes, ensuring environmental security, as well as other benefits from cross-border cooperation.

2. Tourist area Balti. Within this area, monuments of outstanding ecotouristic and scientific value are concentrated, such as the Princely Forest Reserve, the Colonial Birdland Colony, the relict Lake La Fontal, the Cubolta Park, the Landscape Reserve Izvoarele-Risipeni, Aquatic ecosystem "La moara" in Recea, etc. Among the cultural and historical monuments, within the tourist area Balti, can be mentioned churches, historical and art monuments, mansions and castles, ethnographic museums.

The Scientific Reserve "Padurea Domnească" is the largest natural reserve on the territory of Moldova, it has been taken under state protection since 1993 and is one of the most valuable and old European meadow forests, it was established on the forests of the Prut meadow , the detours of Balatina and Calinesti, the total surface being 6,032 ha. The territory of the reserve is a slope with a north-to-south slope, predominantly alluvial soils, meadow chernozems, at the edge, where the forests are in contact with grassy formations salty soils (Bucătari, 2003). Over the past decades, these forests have been destroyed without mercy. Many forests with secular trees have been gutted. Today, measures are needed to re-establish all the stands, moreover the degraded forest sectors and the reconstruction of the other ecological conditions (Postolache, 1995). The data area has a well-developed transport infrastructure, provides road, rail and air links inside and outside the country, offers good access to all tourist attractions. Several regions in the area such as Falesti, Glodeni, Riscani are included in the "Prutul de Sus" Euroregion, and Floreşti is part of the "SiretPrut-Nistru", which makes it possible to better capitalize resources and develop the activity ecotourism, as well as the creation of an attractive natural environment for the development of tourist activities.

3. The Codru tourist area with four sub-areas: Orhei, Teleneşti, Călăraşi, Hânceşti, represents the most important area for ecotourism exploitation, having natural protected areas such as: 2 scientific reserves, 10 nature reserves and 28 nature reserves.

A special interest is represented by the scientific reservations, the "Codru" Scientific Reserve, in territorial aspect, is divided into three sub-zones: the strictly protected area, the buffer zone and the transit area, that is, that portion of the reservation where tourist activities are practiced. The reservation was created for the reason that it is highlighted by its orographic specificity, with old forms of landslides, mosaic of forest soils and rich vegetation (Hojmichi, 2007).

The highest places (maximum altitude $-382 \mathrm{~m}$ ) lie at the basin of the Bîc, Botna and Iagorlîc rivers. The forest vegetation is represented by hardwood, oak, oak and beech forests, of the type of central European forests, which are practically located in the east of their area (Чейдеман, Маник, Николаева, Симонол, 1980).

The second reserve is "Plaiul Fagului", which aims to preserve and study the most representative ecosystems in the area of Codri. Plaiul Fagului, is a picturesque natural scenery, a precious treasure of Moldavian nature. The territory of the reserve is partly accessible for ecological tourism. This complex of natural ecosystems, the site of biodiversity, is an object of research, a laboratory under the open sky. The territory of the reserve is very fragmented as a consequence of erosion and landslides. The maximum altitude is $408.6 \mathrm{~m}$. From here, the Bic River courses and several streams take their course. The reserve flora includes over 900 species of plants, of which 77 are rare, endangered, including vascular plants, macromycetes, lichens, bryophytes (Cuza P., Boaghe, 2003). The largest areas of natural forests are occupied by hornbeams $(31.5 \%)$, crickets $(20.6 \%)$ and carpets $(18.6 \%)$. Fishes occupy 
a comparatively modest surface -256.7 ha, oak forests - only 232 ha. Only in these places in the republic meet the clam, the pearl, to the fly, some rare species of ferns. The fauna is represented by nearly 200 species of animals (Florea, 2005).

The Codru tourist area also has a very rich area of cultural and historical monuments, such as the archaeological reserve Orheiul Vechi, which is a territory with a well-developed and favorable infrastructure for ecotourism, the Codru tourist area represents an important perspective for the development of ecotourism in the Republic of Moldova.

4. The Chisinau tourist area includes forests of landscape, scientific and recreational interest, such as Scorteni, Capriana, lakes and ponds - Chisinau, Ghidighici, Ulmu, mineral waters - Chisinau, Speia, Oniţcani, hunting and pisciculture. The Chisinau tourist area can be considered the second place according to the value of the natural heritage and the cultural-historical monuments, with a well-developed tourist infrastructure due to the geographical position in the area of Chisinau. The city of Chisinau is also known through the Dendrariu Park, Botanical Gardens, Zoological Garden, classified as natural areas protected by the state and which represent important values for the development of ecotourism.

5. The Soroca-Dubasari tourist area with three sub-zones: Soroca, Camenca and Dubasari. Nistru River from Dubasari to its leakage, scientific reserve "Iagorlic", forests of landscape and scientific interest: Cosauti, Holoşnita, Saharna, Cotiujeni, Oniscani, Ţipova, Oxântea, Temeleuţi dendrological park, Holercani rest base important attractions for the development of rest and ecological tourism. We believe that the Soroca-Dubasari area can be a favorable area for starting the cruise on the Dniester River.

6. Tourist area Cahul. This area gives little to the other regions of the Republic of Moldova, imposed by the landscape reserves - Codri Tigheciului, lakes and landscapes from the Prut meadow, pedunculous oaks - Giurgiulesti, mineral waters - Cahul as a spa resort, hunting fund, cultural-historical objectives: Church of Colibaşi, Cheese. Being crossed by transit roads to Ukraine and Romania but having an external position towards Chisinau and other regions of the country, the tourist area of Cahul, through the development of special tourist routes, can promote the image of this region through the following forms of tourism: ecotourism , rest and agreement, treatment, itinerary with historical valences.

7. Tourist area Vulcanesti - Cainari. The main defining elements that attribute to the area a tourist value are: the landscaping reserve of Dezghindea, the Congaz reservoir lake, the Beleu lake, the curative mineral waters - Besalma, Congaz, the fishery and hunting grounds. Featuring modest natural resources but being favored by a modern road network and a railway line, this tourist area, by including its resources in the tourist circuit, can promote eco-tourism, rural tourism, recreation and recreation, hunting and fishing, sports.

8. Lower Nistru tourist area. On the banks of the Dniester, within this area are situated the main recreational objectives such as parks, beaches, landscapes and embankments of the cities of Tighina and Tiraspol, curative mineral waters - Căușeni, the landscape reserve - Turkish Garden in Copanca, medieval fortresses - Tighina, Tiraspol, ethnographic and folklore museums - Olanesti, Tighina, Tiraspol. Within this area, ecotourism can be developed and promoted alongside other types of tourism. In the tourist area Nistru inferior enter the scientific reservation "Iagorlâc". The greatest value of the Iagorlic Nature Reserve lies in the fact that there are many rare and endangered species of plants that enter the unique phytocoenoses situated on the Iagorlic river steppe slopes. The meadow vegetation occupies small areas in the valley of the Iagorlic River. In the vicinity of the river banks there were recorded not too large areas of marsh vegetation with the predominance of the following 
species: rogoz, reed, rush, lily-of-the-valley, aquatic patch, yellow-stony, obligenel (Bejenaru, 1998).

\section{CONCLUSIONS}

Areas protected by their natural value and low levels of human intervention on their territory are the best examples and models for natural and semi-natural ecological systems. Thus, both the assessment and monitoring of the state of natural capital and the development of ecotourism can be achieved in pilot areas such as the eight tourist areas. Protected natural areas, through their aesthetic, recreational, educational, scientific interests, are very attractive tourist attractions in the field of ecotourism and are also a major point in its development. Their protection, capitalization and promotion have long-term economic and social benefits as they serve as a basis for the sustainable development of ecotourism but also for an economic establishment for the resident population.

The Republic of Moldova has a rich area of natural objectives and complexes of tourist importance, which allows the development of ecotourism as a sustainable form of tourism. It is worth noting the presence of natural ecosystems that have the potential to develop ecotourism in protected areas and other natural areas, which have good natural conditions for outdoor activities: hiking, flora and fauna observation, sports and cultural activities.

\section{REFERENCES}

Bejenaru, I. (1998). Protecția patrimoniului natural. Chișinău: Editura Știința.

Bucătari, S. (2003). Zona de protecție integrală din rezervația științifică Pădurea Domnească. Mediul Ambiat, nr 6, din 11.12.2003.

Cuza, P., Boaghe, D. (2003). Ecosisteme forestiere. Rezervația naturală de stat Plaiul Fagului. Chișinău: Editura Universul.

Florea, S. (2005). Potențialul turistic al Republicii Moldova. Chişinău: Editura Laberint.

Hojmichi, C. (2007). Obiective turistice din țară. Dezvoltarea $\mathrm{nr}$ 20, 25.05.2007.

Postolache, G. (1995). Vegetația Republicii Moldova. Chișinău: Editura Știința.

Чейдеман, Т.С., Маник, С.И., Николаева, Л.Т., Симонол, Ч.П. (1980). Конспект флоры заповедника Кодры. Кишинев.

DOI: 10.7862/rz.2019.mmr.9

The text was submitted to the editorial office: June 2019.

The text was accepted for publication: June 2019. 